\title{
Grand narratives then and now: Can we still conceptualise history?
}

\author{
Helena Sheehan
}

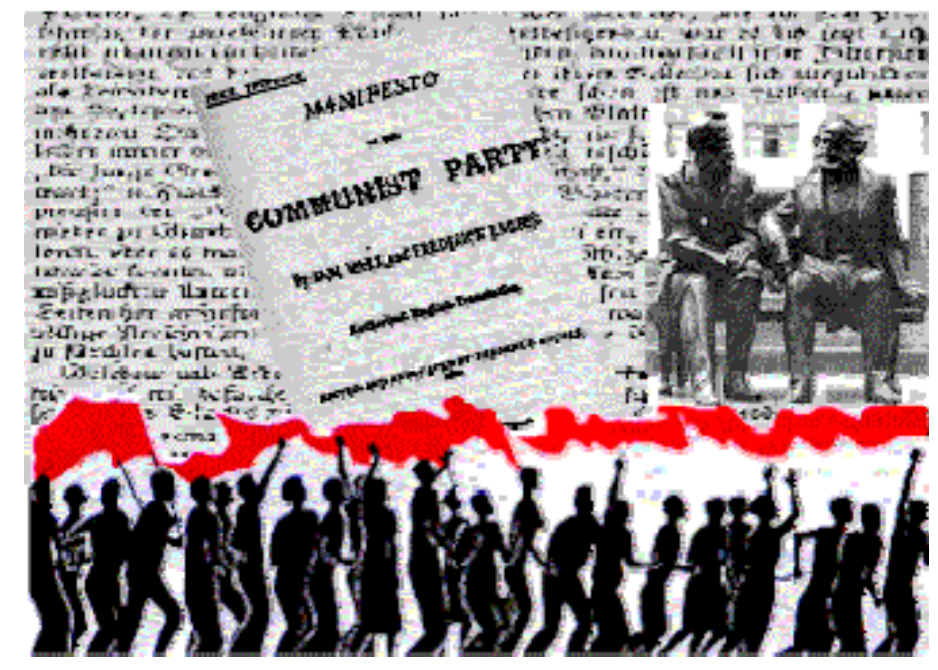

(collage by H Sheehan)

This is a paper written for the 150th anniversary of the Communist Manifesto for an international conference in Paris from 13 to 16 May 1998

“Quelle alternative au capitalisme? Quelle émancipation humaine?"

It has since been published in Socialism and Democracy vol 12 no 1-2 1998.

Reading the Communist Manifesto today, it is impossible not to be struck by the confidence with which it conceptualises history. The positive energy of this bold grand narrative stands in such stark contrast to the negative and jaded mentality of our times, which conceives of grand narratives only to tell us that there can be none. Such talk as there is of history today is more likely to be of "the end of history". There are three senses in which references to the end of history feature in contemporary debates: apocalyptic prediction, postmodernist pronouncement and capitalist triumphalism. This paper addresses the crisis of historicity in our time in relation to these positions and asks what is it about our age that produces them. It explores the widespread rejection of grand narratives, as well as grand narratives, which nevertheless persist, implicit and explicit, right and left. It looks at the position of marxism in the 1990s, 
counterposing it to postmarxism and postmodernism in particular on the question of grand narratives. It calls for resistance to the detotalising pressures of the age and revival of a totalising (as opposed to totalised) philosophy of history.

Quand on lit Le Manifeste communiste aujourd'hui on est frappé par la confiance avec laquelle il conceptualise l'histoire. L'énergie positive de ce grand récit audacieux contraste cruellement avec la mentalité négative et blasée de notre époque qui nous parle des grands récits seulement pour nous dire qu'ils ne peuvent pas exister. Quand on parle de l'histoire aujourd'hui, c'est plutôt pour évoquer la 'fin de l'histoire.' Les références à la fin de l'histoire dans les débats contemporains sont de trois ordres: la prédiction apocalyptique, la déclaration postmoderne et le triomphalisme capitaliste. Cette intervention s'adresse à la crise de l'historicité de notre époque par rapport à ces prises de position et se demande pourquoi notre époque les engendre. Nous explorons à la fois le rejet presque universel de ces grands récits et la persistance, implicite et explicite, des grands récits, à gauche et à droite. Nous examinons la position du marxisme dans les années 90, le mettant en opposition au postmarxisme et au postmodernisme surtout au sujet des grands récits. Notre intervention appelle à la résistance contre la presssion détotalisante de notre époque et à la renaissance d'une philosophie totalisante (par oppostion à totalisée) de l'histoire. (translation by Michael Cronin)

Reading the Communist Manifesto today, it is impossible not to be struck by the confidence with which it conceptualises history. It pulsates with vitality, vision, verve. The positive energy of this bold grand narrative stands in such stark contrast to the negative and jaded mentality of our times which conceives of grand narratives only to tell us that there can be none.

Such talk as there is of history today is more likely to be of "the end of history". There are three senses in which references to the end of history feature in contemporary debates: The first is apocalyptic prediction: that, through nuclear war or ecological catastrophe, our world will come to an abrupt end and so that will be the conclusion of the human story. The second is postmodernist pronouncement: that there is no such story to tell, nor is there any such thing as a coherent subject able to tell such a story. The third is capitalist triumphalism: that the story has played itself out in the sense that the plot has reached its conclusion and there is no further suspense or striving toward alternative outcomes.

Assuming that we manage to avert the annihilation of our species and our world, where do we stand then? Where are we in our story? Is there even such a thing as a coherent "we" or a coherent "story"? Have we nevertheless come to the end of history? There are many voices telling us so. There is undoubtedly a crisis of historicity in our times.

Why? Such is the complexity and fragmentation of contemporary life that it seems increasingly impossible to unify experience into a coherent narrative, either on the level of psyche as biography or on the level of society as history.

Postmodernism, with its proclamation of the end of grand narratives, represents the contemporary crystallisation of this mood. However, the prohibition on overarching historical schemes predates 
postmodernism. It has been a feature of most other philosophical currents of our century: logical positivism, linguistic analysis, pragmatism, existentialism, phenomenology, poststructuralism.

Standing opposed have been the surviving grand narratives of the premodern era, predominantly those of the great world religions, such as christianity and islam. There has also been the formidable grand narrative of the modern era: marxism. All of these have been, not only under external attack, but subject to tendencies eroding them from within.

The rejection of grand narratives raises searching questions: What is it about our times that produces such intellectual fragmentation? Why all these pronouncements that there are no laws, that there is no truth, that there is no meaning, that there is no progress? Why are we told that we have witnessed the death of philosophy, that we have come to the end of epistemology, the end of aesthetics, the end of ethics?

There is something in the very essence of the present social order, which structurally inhibits integrated thinking, which undermines the very foundations of rationality and sanity and morality. There is something at the very core of contemporary experience, which blocks access to totality, which keeps theory flying so far from experience and keeps experience groping so helplessly in the dark. Only by breaking its boundaries, only by penetrating to the very source of the society's inner tensions and perceiving the mechanism generating the fragmentation, only by naming the system and taking it on, can the way beyond it be discerned.

In the contemporary world system, with the forces at work being so faceless and so distant and with the overall process seeming so impenetrable and out of reach, the attempt to understand the world and to get a grip on it has given way to various ideological strategies, from various forms of premodernism to postmodernism, functioning either to evade or to justify the impenetrability and dislocation.

The left has always been divided on this, never more so than now. Social democrats, consonant with their distancing from marxism, have renounced grand historical schemes in favour of piecemeal social engineering, adopting the position of Karl Popper in The Poverty of Historicism. A document presented for discussion in the Labour Party in Ireland in recent years was prefaced by the following quote from british historian H Fisher:

Men wiser and more learned than I have discerned in history a plot, a rhythm, a predetermined pattern.

These harmonies are concealed from me.

I can only see one emergency following upon another as wave follows upon wave.

Gunter Grass in From the Diary of a Snail renounces the runaway stallion of the weltgeist in favour of the snail's journey of social democracy, but faces up to the drawbacks of his own position:

Even in our dreams we sighted no new land...

Where is the push if nothing pulls?

Something is always lacking.

What?

Serviceable foundations, a framework, formulations of goals ... 
When I spoke with Grass in Dublin in 1991, I kept quoting him at himself whenever debate turned this corner: Where is the push if nothing pulls? Why not do the hard work of providing ourselves with serviceable foundations, of constructing a credible framework, of formulating viable goals?

I believe that we should be bold and take on the thrust to totalisation, as an open-ended, always to-berevised process. I cannot see how it is possible to go from one day to the next without a sense of the story in which my days take their shape: the story of my own life within the story of the world in my time within the story of the human species within the story of the universe.

Of course, my knowledge of the details of the story become sketchier as the circle widens and the narrative becomes grander. I am not omniscient. I am not an expert in astrophysics or molecular biology or medieval history or contemporary economics. Nevertheless I do have a sense of the origin of the universe, the evolution of species, the transition from feudalism to capitalism, the emerging shape of the globalised market of our time.

With such imperfect knowledge as I have at any given time, I pull together as much as I can know and synthesise it in the best way I can. The next day I may question it or revise it or refine it, but I cannot live without it. So I get on with it and I believe that many others do so as well, even if only implicitly and incoherently. I would argue that it is better to do it explicitly and coherently, to articulate criteria for doing it, to take responsibility for doing it,

However, I feel acutely the hostile climate in which I do it, especially as I do it within the intellectual tradition stemming from the Communist Manifesto.

I am not the only one to feel this. At a conference on gender and colonialism at University College Galway in the early 1990s Terry Eagleton spoke of feeling an endangered species as a male middle-aged marxist fenced off by barbed wire with a sign on it saying: "BEWARE: It totalises and reduces." At the IAMCR (International Association for Mass Communication Research) conference in Dublin, Colin Sparks referred to marxism as "the philosophy that dare not speak its name".

At a philosophy conference at the Royal Irish Academy (I am ashamed that we are still calling it "royal"), I engaged in a brief and utterly unproductive clash with Hilary Putnam, Harvard philosopher and onetime marxist, who wrote off the whole of marxist intellectual traditions as "just junk". In philosophy departments, east and west, marxism has disappeared from course catalogues. In some quarters, it has been airbrushed out of the history of philosophy.

Even within the intellectual culture of marxism, in some of the places you might be looking for an oasis of understanding, it is possible to feel very isolated in these years,

Speaking at a session on marxism and beyond at a futures event organised by Marxism Today in the last days of the CPGB, my defence of marxism as a totalising (but never finally totalised) historical perspective was prefaced by the chair announcing (as if it were taken-for-granted common sense) that marxism had lost its all-round explanatory capacity. My argument about the role of Marxism Today as making every sphere so autonomous as to dissolve the pattern of interconnections making marxism what it distinctively is was met with astonishment at my "combative confidence" and calling for a "more modest approach". Around the same time I had an encounter with a postmarxist, who accused me of "epistemological imperialism". 
Another encounter along these lines was set up by the trade union MSF (now Amicus) as a debate between myself and Proinsias De Rossa, leader of Democratic Left and subsequently a government minister. My text European Socialism: A blind alley or a long and winding road? Reflections on the trajectory of history along his response was published as European Socialism: A New Beginning. We agreed on important matters, but he also took issue with me on many points, in a way that was a reasonable reflection of real points of cleavage on the left, as we have struggled to sort ourselves out at this very difficult point in our history. He took a much more distanced view of Eastern Europe and did not feel so implicated as I did in the socialist experiments of the past and therefore argued that the left in the west ought not be so affected by what has happened in the east. But the most fundamental divergence between us, I think, was on the question of grand narratives.

He brought various quotes to bear in articulating his uneasiness with the concept of grand narratives, with talk about "history". He recounted how Mao, when asked whether French Revolution had been a success, replied that it was too soon to say. He told of an exchange in the House of Commons in which David Owens suggested that history would bear him out, at which point a tory backbencher shouted across the floor that he was sure that history had better things to do. He quoted Keynes' observation that in the long run we are all dead. He said himself that grand narratives aren't much use when your head is being stuffed in a gas oven or starving to death or if you are a long term prisoner of conscience. He said that, when he came across problems of poverty, unemployment and injustice, he didn't think about the trajectory of history.

\section{I do, however.}

Eastern Europe has receded from the international news agenda. We have all got on with our lives. Nevertheless, the questions these events posed for the left about the direction of history remain. My own efforts to come to terms with such questions can be found at:

\section{Has the red flag fallen? \\ European socialism: a blind alley or a long and winding road?}

About poverty and unemployment and injustice, it is possible to be sensitive to the concrete and particular, even while seeing them in a larger, deeper and fuller context. The only larger story that is worth telling is one that is grounded in the intricacies of what happens, discovering much as we go along. In fact, I believe that being in the process of constructing this story all the time involves greater sensitivity to the particularities of it.

Some will shake their heads and see only plurality and miscellaneity and dismiss as delusions of grandeur all striving to discern any underlying pattern in what they regard as random chaos. Nevertheless, I persist, believing that is better to strive for sense than to settle for nonsense.

Marxism is crucial to this. What has set marxism apart from all other modes of thought is that it is a comprehensive world view grounded in empirical knowledge and socio-historical process. All economic policies, political institutions, legal codes, moral norms, sexual roles, aesthetic tastes, thought patterns and even what passes as common sense, are products of a particular pattern of socio-historical development rooted in the transformation of the mode of production. It is not a pre-determined pattern or a closed process. Although there is a determinate pattern of interconnections, the precise shape of 
socio-historical development is only discernable post factum, for history is an open process, in which there is real adventure, real risk and real surprise, a process in which there are no inevitable victories.

I realise that not all who have called themselves marxists would accept this conception of it, even in the broadest outlines. The marxist tradition has been full unto overflowing with argument and controversy. As well as scientific, humanistic and historicist currents, there were anti-scientific, anti-humanist and anti-historicist currents.

There are, moreover, areas in which marxism has remained woefully underdeveloped. Aside from its inability to deal honestly with its own history, a particularly serious failure in a historicist philosophy, there were also its failure to come to terms with the emergence of new social forces, its neglect of the whole field of human psychology, its inadequacy in dealing with the moral dimension. I believe that marxism has within itself the capacity to illuminate these areas in a way that is superior to any other contenders, even those which dealt with these areas more directly.

As to whether it is too soon to say about our own times, there is a dimension of truth in this, insofar as the meaning of events is never fixed and our comprehension of the course of history does deepen and expand as we go on with it. But when do we start? To take this too far, it will be forever too soon and we succumb to plodding particularity and eccentric eclecticism. We shall be forever too busy going somewhere to have any notion of where we are going. I say that it is never too soon to say, even if we can say better tomorrow about today than we can say today. We have a better chance of comprehending better tomorrow, if we have striven to comprehend as best we can today.

No textbook of historical materialism will do this for us, but it will give us clues as to possible patterns of interconnection and inculcate the habit of looking wider and deeper than is the fashion.

Yes, in the long run, we'll all be dead. But it is a matter of how wisely and how fully and how progressively we shall have lived.

Postmodernism in particular bears witness to the disintegrative power of contemporary capitalism. The fact that it has taken hold within the left is symptomatic of the left's paralysis in the face of the impenetrability and complexity of the system. Those who have renounced any sort of drive towards totalising historical perspective in the name of marxism have only muddied the already muddy waters, whatever their intentions. In some cases, they have been so overanxious to avoid the distortions of economic reductionism as to negate the role of economics altogether and to make every sphere so autonomous as to dissolve the pattern of interconnections making marxism what it distinctively is.

The crisis of marxism in our times has grown out of the detotalising pressures of the age as well as out of reaction to a fossilised totality. The phenomenon called postmarxism testifies both to the need for further development of the tradition and a paralysis before the task of doing so.

Once the totality comes unravelled and core concepts such as class and mode of production are let to fall, there is only the populist pluralism of public opinion polls and focus groups, the born-again discovery of the complexity of the market, the blandness of citizenship, the justification of conspicuous consumption, with special pleading for compassion for the underprivileged tacked on, the preference for alliances to the right and the burning of bridges to the left. New Labour ingratiates itself to monarchy and media moguls and turns its back on the trade union movement. 
Many marxists, who were once in marxist parties, are now in social democratic ones. I am myself. Some are no longer marxists, but others still are, believing that it marxism has much to offer to the intellectual life of these parties, which tend to be driven by narrowly conceived policy formation and lacking in systemic analysis and historical perspective.

Whatever marxism is, it is systemic analysis and historical perspective. It is a totalising (not totalised) philosophy of history. It is the only mode of thought able to give a coherent, comprehensive and credible account of the complexity of contemporary experience. It is the only coherent analysis of the capitalist mode of production and how it structurally generates, not only the maximum expropriation of surplus value, but maximum dissolution of social bonds, involving decreasing access to totality and increasing atomisation of thought processes. It is the only credible analysis of an alternative mode of production, proposing socialism, not only as a radical restructuring of the relations of production, but as a fundamental transformation of patterns of thought and forms of social organisation.

Marxism has been marginalised. Indeed, in many quarters, it seems to have disappeared. But those who have been touched by in on a deeper level and not been swept off their feet by postmodernist pastiche or capitalist triumphalism are better adapted to new times, because we have a way of understanding and dealing with it that is denied to those thrown up by it, but who do not understand it, changing with every fashion, but having no inner core to hold them together from one fashion to the next.

Marxism may have been marginalised, but it has not been refuted. There is still nothing to match it in explanatory power or moral vision. It is still the unsurpassed horizon of philosophy in our times. Nothing else has yet come even close to it.

A few years back, Fredric Jameson spoke of how at a marxist conference he began to feel as if he were one of the few marxists left. So be it, he said, and took it that he had the responsibility to restate a few truths, which he considered to be self-evident, but others did not, breaching the taboos of postmarxism, including the stigmatisation of the concept of totality and of the project of totalising thought.

Against this background, it has been interesting to note that two of the most influential books of the early 90s have been totalising historical projects, attempts to conceptualise the present within an overarching scheme embracing past, present and future. Both Francis Fukuyama's The End of History and the Last Man and Fredric Jameson's Postmodernism, Or, The Cultural Logic of Late Capitalism are grand narratives, the one from the right and the other from the left.

Fukuyama's version of the shape of history has broken beyond the boundaries of academic discourse into mass media expose and compulsory cocktail party chatter in a most spectacular way. The original article "The End of History?" published in a small-circulation neoconservative journal The National Interest in the summer of 1989 soon was, as one news vendor put it, "selling better than pornography".

Why ? It was, according to a commentator on BBC's The Late Show: "the right man saying the right thing at the right time". It was not meant, I think, as double entendre, but the word right could be taken both ways.

By "the end of history" Fukuyama did not mean what postmodernists or neopositivists mean, nor did he mean what the proverbial man-in-the-street took it to mean. He did not mean that it was no longer possible to tell any sort of coherent story regarding the broad sweep of human events. Quite the 
opposite. Here was as big and bold a story as could be told. In fact, it had such a strong predictive pattern that he could articulate the end point of the process. But this end did not mean an end to empirical human events. It meant an end to any credible intellectual debate about the framework within which these events would or should occur.

The book, appearing three years later, was a more elaborate argument, going into much more detail about the philosophical basis of his position, as well as the empirical evidence for it, and answering criticisms from all directions. Also, interestingly, "the west has won" triumphalism, which captured the mood of the time to which his original thesis spoke and to which it owed its spectacular success, was toned down and his conclusion was much more tentative.

He was resolute, however, about the defence of his philosophy of history. While conceding that it flew in the face of the main currents of thought this century, he nevertheless insisted that history is an intelligible and directional process, that there is an underlying connecting thread pulling the most diverse happenings together into a meaningful whole. Against the fashion in the social sciences claiming that every case is different, he maintained that there is a common evolutionary pattern in all societies and that it is progress toward liberal democracy. Although modernisation theory fell victim to charges of ethnocentrism, he argued, the truth of it would become more apparent as more people's point of view became more cosmopolitan.

With the victory of liberal democracy over absolute monarchy, fascism and communism, it stood, according to him, as the final form of human government and the end point of ideological evolution. There were no alternatives left in the field to challenge it on the level of ideas: "we cannot picture to ourselves a world that is essentially different from the present one, and at the same time better". He did not, however, find anglo-saxon empiricism to be an adequate theoretical basis for liberalism and counterposed german idealism to it as an alternative basis. The bourgeois is selfish: that was the core of critiques of liberalism from both left and right, which he set out to examine.

It was here that the triumphalism began to unravel. At one moment he was arguing that liberal democracy is the end point of human evolution, because it represents the resolution of all contradictions and therefore the closure of the dialectic, the end of history. The next moment he was immersed in a quagmire of contradictions, which he acknowledged as the contradictions of capitalism. The social problems of the US in particular and the capitalist world in general, which his critics pointed out to him, he admitted, but he answered that they were grounded, not in the principles of liberalism, which could not be improved upon, but in the incomplete implementation of those principles. However, he later conceded that liberal economic principles destabilised community, eroded social discipline and undermined the work ethic on which capitalist productivity depends. Societies based on a language of good and evil were bound together more strongly than those based merely on shared self-interest.

One moment he was extolling the victory of the vcr and the virtues of the USA as the best of all possible worlds and the next he saw it as seething in its own inextricable contradictions, which would be the seeds of its destruction. He retreated from the french revolution to the ancien regime, from democracy to aristocracy, from liberalism to conservatism, from historicism to essentialism, from Hegel to Plato. But then he advanced back again, back and forth, shifting his ground over and over again. For having begun with such a strong positive thesis, the book ended in a strange confusion and inconclusiveness. 
A few years later Fukuyama was back on the international circuit, following upon the publication of his latest book Trust. He was articulating the downside of liberalism even more strongly and articulating its contradictions even more clearly. The US, he claimed, was destroying its own moral base. Liberal democracy, capitalism, was not sufficient. It had to be supplemented by preliberal, precapitalist moral notions and cultural institutions. People had become too aggressive about their rights, too individualist, too selfish. He spoke highly of 1950s America, as well as contemporary Germany and Japan, as societies embodying both economic prosperity as well as a social cohesion and trust.

Introducing Fukuyama on The Big Idea on the BBC, Andrew Marr asked: "Is he the Adam Smith of our times or just a phrasemaker with great pr?" I believe that he is neither. He is a serious thinker dealing with history from the right on the scale on which we should be dealing with it from the left. Most responses from the left have been far too flippant, flimsy and feeble.

When the earlier book came out, The Late Show on BBC did a feature on it. Denis Healy gushed with condescension, telling Fukuyama that he reminded him of his youthful marxist self. Now he knew better, he smugly pronounced: History is absolute bunk and Karl Popper proved it. However, Fred Halliday and Stanley Aronowitz on the same programme recognised that the questions raised had to be addressed on the same level of generality as Fukuyama had done, that the left had to realise that what is up for grabs is history itself. The big questions have to be engaged: Is history possible? What moves it along? Where is it going?

Perry Anderson argued along similar lines in a long chapter "The Ends of History" in A Zone of Engagement, devoted largely to the Fukuyama phenomenon. He contended that the effect of withdrawal of the left from the arena of macro-narratives is to leave the right version in possession of the field. If the Fukuyama variant is to be questioned, it must be on its own legitimate, and even inescapable, terrain. Philosophies of history will not go away, he insisted.

Ironically even those who announced the end of philosophies of history have testified in their unintended way to the fact that philosophies of history will not go away. Not least among all the paradoxical pretentions of postmodernism is how even the theory of the end of master narratives is cast in the form of a master narrative. Jameson has perceptively characterised postmodernism as representing the unforeseen return of narrative as the narrative of the end of narrative, as the unforeseen return of history as prognosis of the end of historical telos.

Jameson's Postmodernism, Or, The Cultural Logic of Late Capitalism has moved in the arena of philosophy of history, not only giving a spirited defence of totalising thinking, but engaging in concrete totalising thinking to map the terrain of our times. In the midst of a crisis of historicity, postmodernism, despite itself, can be seen an attempt to think historically in an age that has forgotten how to think historically, to take the temperature of an age without instruments, in an age when we are no longer sure that there is a thing so coherent as an 'age'. It seizes upon the very uncertainty of our age as its first clue, holding on to it as its Ariadne's thread through what may turn out to be not a labyrinth, but a gulag or perhaps even a shopping mall. All analysis of particular events, he argued, involves a buried or repressed theory of historical periodisation. Even the initial decision as to whether there is such a grand scheme, as to whether what one faces is chaos or continuity is based on an inaugural narrative act that grounds the perception and interpretation of the events to be narrated. 
He saw postmodernism in terms of mode of production, as the force field, as the cultural dominant, within which very different impulses, residual and emergent forms, have to make their way. It is the logic of late capitalism, experienced as schizophrenia, as heterogeneity, as randomness, as chaos, as undecidability.

The irony is that underlying all the rhetoric of pluralism and difference and the attacks on history and totality is the fact that capitalism has inaugurated a new kind of total history. There has never been such a systematising and unifying force as late capitalism. There has never been such a global and totalising space as that of the new world system. It is a system so omnipresent as to be invisible. Where everything is so systemic the concept of system seems to lose its point.

It is a system in which the structural co-ordinates are no longer accessible to immediate lived experience and no longer imaginable or conceptualisable to most people. This makes it all the more difficult, but all the more imperative, to name the system and to engage in the process of cognitive mapping. The waning of a sense of history and the resistance to globalising and totalising concepts is a function of globalising and totalising capitalism.

Against this, according to Jameson, a more global characterisation of all the secret affinities, a historical reconstruction of the hidden rhythms in all the blooming, buzzing confusion of immediacy is a unique resource, the basis of radical intervention in the here and now, the promise of resistance to its blind fatalities. It is diagnostically better to have a totalising concept than to try to make one's way without one. There can be no radical critique of capitalism or resistance to it, he insisted, without reflection on the nature of socialism as an alternative system.

It is only within the marxist tradition, I suggest, even in the bloodied state in which it now finds itself, that we get the really bold and brave thinking that is needed to come to terms with the times.

I spent much of the 1970s writing a book Marxism and the Philosophy of Science: A Critical History. It was published in the US in the 1980s. Given the climate of the early 1990s, I was surprised when my publisher decided to bring out a new paperback edition. I was asked to write a new introduction, The fate of marxism, which forced me to think about the 'now' of the text and the 'now' of the new edition, which meant writing about where things stand with marxism in the 1990s.

I give lectures on marxism in my courses at Dublin City University and put up web pages on marxism at the DCU website indexed at http://webpages.dcu.ie/ sheehanh/sheehan.htm. This semester I did an elaborate multimedia presentation on marxism. It could be said that I am playing to the MTV generation. Maybe so, but I believe that new conditions, new technologies offer new opportunities, even better ways of doing things. The ideas of marxism have always been integrally bound up with a political movement navigating the waves of history. It is truer to the subject matter to present the ideas with the images and sounds of a living breathing historical force. To what effect? I don't know. I am not being swamped by students wanting to change the world or even to do theses on it, but I think that I convince them that it is worthy of respect, that it is a major intellectual tradition in the history of human thought and a political movement that has set this century on fire.

Despite everything, I believe, it still has an explanatory and ethical power, persisting through all its problems and cutting through all the confused and craven chatter surrounding it. It is not so much in any of its particular tenets, as in its orientation to large-scale and deep-rooted thinking, in discerning the 
trajectory of history as it comes, looking for a pattern of interconnections, where others see only random chaos, going further back into the past, reaching wider within the present and facing with greater composure into the future.

So, wherever we are in our story, we have not come to the end of history, not in any sense of the term:

1) Despite all prophecies of nuclear or environmental catastrophe, we have not come to the end of history in the sense of our species ceasing to exist. We survive.

2) If we are brave and disciplined enough to make the effort, we can look and listen, we can analyse and synthesise, we can transcend postmodernist paralysis and have a story to tell, the story of our own times.

3) We can counter the story that Fukuyama is telling. We can say that we can imagine a world that is different from the present and at the same time better. We can in our thought and in our lives show that the battle of ideas, rooted in the struggle of contending forces in the world, has not yet been won. There is much more to be said. There is much more to be done.

It is not the end of history, not in any sense.

References:

Karl Popper The Poverty of Historicism London, 1961

Gunter Grass From the Diary of a Snail London, 1989

Helena Sheehan "Of Snails and Sisyphus" Graph 11 Winter 1991-92

Francis Fukuyama The End of History and the Last Man London, 1992

Francis Fukuyama Trust: The Social Virtues and the Creation of Prosperity NY 1996

Perry Anderson A Zone of Engagement London, 1992

Fredric Jameson Postmodernism, Or, The Cultural Logic of Late Capitalism London, 1991

Helena Sheehan Marxism and the Philosophy of History: A Critical History Atlantic Highlands, NJ, 1985, 1993

Proinsias De Rossa and Helena Sheehan European Socialism: A New Beginning Dublin, 1992

Website: http://webpages.dcu.ie/ sheehanh/sheehan.htm

E-mail: helena.sheehan@dcu.ie 